\title{
Delayed Charge Time
}

National Cancer Institute

\section{Source}

National Cancer Institute. Delayed Charge Time. NCI Thesaurus. Code C63280.

Problem associated with an unexpected amount of time required to charge the device (e.g. a delay in starting charging or a longer than expected charge time). 